Historic, Archive Document

Do not assume content reflects current scientific knowledge, policies, or practices. 

62.73

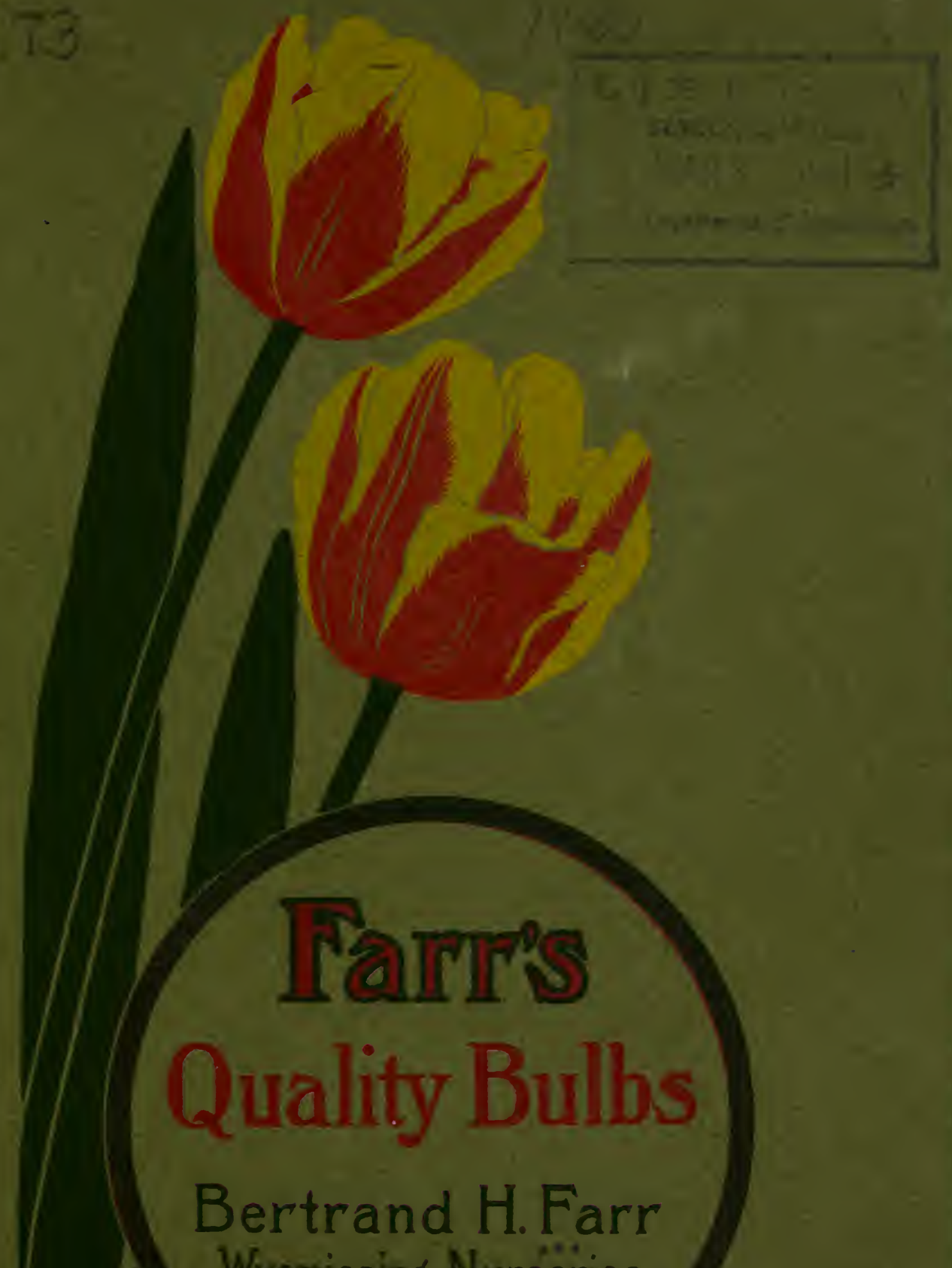
A Wyomissino Nurseries

Nyomissing. $\mathrm{Pa}$.

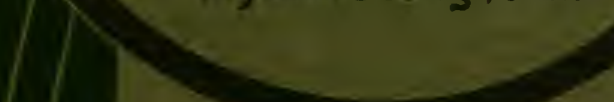




\section{BULBS FOR FALL PLANTING}

7 ONDITIONS in the Holland bulb frelds remain about the same as for the past three or four years; there is little, if any, increase in the quantity of stock produced by the various growers. To offset this, however, there is a noticeable improvement in the quality of the bulbs which are offered for the coming season. I have been fortunate in securing my bulbs from the same sources that have furnished me in past years, so I am confident that the Hyacinths, Tulips, Narcissi, and other fall bulbs will this year be even better than those I have sent to my customers during the past.

While I contract for enough bulbs to fill the orders of my regular customers, it must be understood that these bulbs are not carried in stock, and that my importations are regulated by advance orders received from customers before July 15 .

Prices are based on current quotations at which I have placed my order with the growers. Importations to America will be very light this year, and it will be almost impossible to make up shortages later in the season. You can realize from this how important it is to both of us that

YOUR ORDER SHOULD COME TO ME NOT LATER THAN JULY 15

In accordance with my established custom, I allow a special discount of 10 per cent on all orders for Narcissi, Tulips, Hyacinths, and Lilies received before July 10. After that date no discount will be given.

Terms cash, unless other arrangements have been made. Orders from unknown correspondents, without satisfactory commercial rating, should be accompanied by remittance to cover the order, or by bank reference. Please remit by post office or express money order, registered letter, bank draft, or check.

\section{IRISES THAT MADE WYOMISSING FAMOUS}

Most of these Irises are known to my regular customers, and to some their cultivation has become an interesting and diverting hobby. Gardeners who are not acquainted with these Irises have a world of pleasure awaiting them. The best time for planting is in August or early September, for just then they pause before resuming a new period of growth. AII of the Bearded Irises, thrive in a dry, sunny situation. Irises of the Beardless type, including the Japanese Irises, require more moisture, but will grow in any good soil that is kept mellow during the growing season. In my collection, which includes several hundred varieties, there are Irises which cannot be obtained elsewhere, as well as the more familiar sorts.

\section{FARR'S HARDY PLANT SPECIALTIES}

(Seventh Edition)

This handbook of Hardy Plants, Shrubs, and Evergreens has been completely revised during the past few months and is nearly ready for distribution. A copy will be sent to my regular customers without further notice. If your name is not on my list, a copy will be sent on request.

\section{BERTRAND H. FARR - Wyomissing Nurseries Co. May 1, 1920 WYOMISSING, PENNA.}




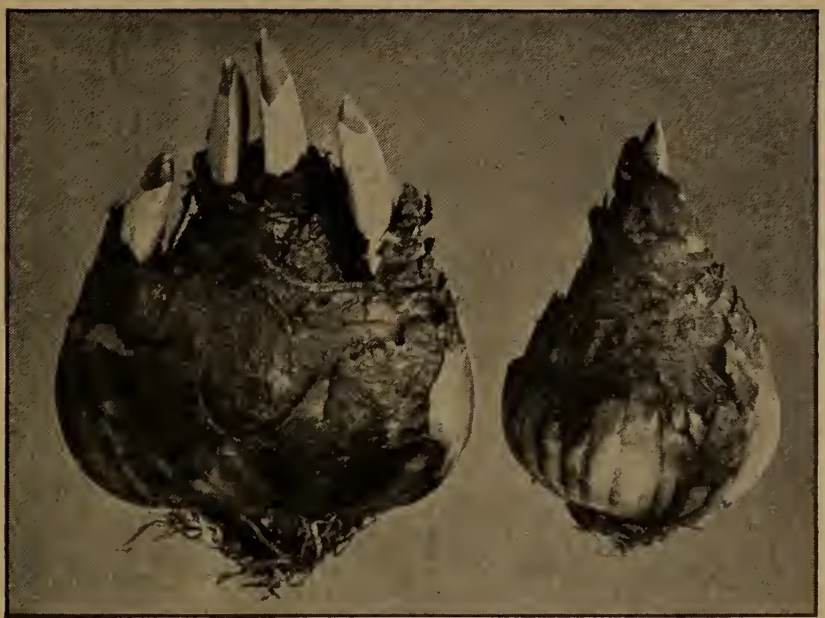

Bulbs of Sir Watkin Narcissus. Showing Farr's "Mother Bulb" in comparison with the ordinary first-size bulb

\section{DAFFODILS (NARCISSI)}

Daffodils will continue to increase every year, and, when naturalized on the lawn, in meadows, or in orchards, they will form great colonies. They are invaluable for planting among shrubs and in the hardy border, and especially among the peonies, their golden cups making a beautiful contrast with the bright red peony shoots coming out of the ground.

"Mother BuIbs" (of ten called "double-nose") are those that have reached maturity and are about to break into several smaller bulbs. The "Mother Bulbs" will send up several flower-stems, whereas the ordinary bulbs seldom produce more than one stem. So many of my customers call for "Mother Bulbs" that I have decided not to list the common "first-size" bulbs.

\section{SINGLE LARGE TRUMPET NARCISSI (AJAX)}

These are the true Daffodils and produce the Iargest flowers. Colors range from pure white to darkest yellow.

Not less than six each of any one variety will be supplied, except the new high-priced kinds where the rate for a single bulb is specifically quoted

To obtain the dozen rate your order must be for six bulbs or more of one variety. Less than six bulbs will be charged at the single rate

Albicans. Sulphur-white. \$I per doz., \$6.50 per roo.

Bicolor, Empress. (Mother.) Large yellow trumpet with pure white perianth. This variety and Emperor are the most permanent sorts for naturalizing. \$1.25 per doz., \$9 per roo.

Bicolor, Van Waveren Giant. Widely expanded, bright yellow trumpet, with broad primrose perianth; said to be the largest trumpet Narcissus in existence. Strong grower. 40 cts. each, $\$ 3.75$ per doz., $\$ 27.50$ per 100 . 


\section{BERTRAND H. FARR-WYOMISSING NURSERIES CO.}

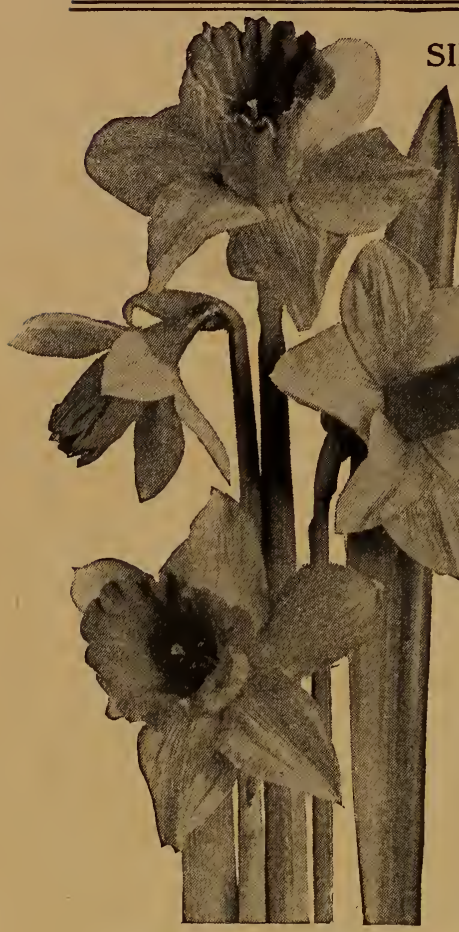

Mme. Plemp. Excellent for border planting

Trumpet maximus. Deep golden yellow; perianth twisted at tips; trumpet recurved. \$I per doz., \$6.50 per Ioo.

\section{SINGLE MEDIUM TRUMPET NARCISSI}

(Chalice Cup, or Star Narcissi)

In the Barrii type, which is a cross between the Trumpet and Poeticus groups, the crown or cup is about half the length of the perianth segments.

The Incomparabilis types are also crosses between the Trumpet and Poeticus groups, but the crowns are larger than Barrii, of ten three-quarters the length of the perianth.

Leedsii Narcissi are crosses between the white Trumpet and Poeticus groups. The cup or crown is white or light yellow, and the perianth is always white.

Barrii, Blood Orange. Lemon-yellow perianth; orange cup. $\$ 1.50$ per doz., \$7.50 per roo.

Barrii, Conspicuus. (Mother.) Perianth broad, soft yellow; orangescarlet cup. Splendid for borders. 75 cts. per doz., $\$ 4$ per roo, $\$ 40$ per I, ooo.

Barrii, Firebrand. Primrose perianth, red cup. \$1 per doz., \$7 per Ioo. 


\section{SINGLE MEDIUM TRUMPET NARCISSI, continued}

Barrii, Seagull. White perianth; canary-yellow cup. $75 \mathrm{cts}$. per doz., $\$ 4$ per Ioo.

Incomparabilis, Cynosure. Primrose-yellow perianth; yellow and orange cup. A showy sort for naturalizing. $6_{5}$ cts. per doz., \$4 per Ios, \$35 per I, 000.

Incomparabilis, Cloria Mundi. Yellow perianth; orange - scarlet cup. \$1.20 per doz., $\$ 6.50$ per 100 .

Incomparabilis, Lucifer. White perianth; orange-red cup. \$1.25 per doz., \$6.50 per Ioo.

Incomparabilis, Sir Watkin (Giant Chalice Flower). Extra large; sulphur-yellow perianth, orange-stained cup. \$I.5O per doz., $\$ 9$ per Ioo.

Incomparabilis, Stella. Pure white perianth; yellow cup. Good variety for potting. $80 \mathrm{cts}$. per doz., $\$ 4.50$ per I0o, $\$ 40$ per I,000.

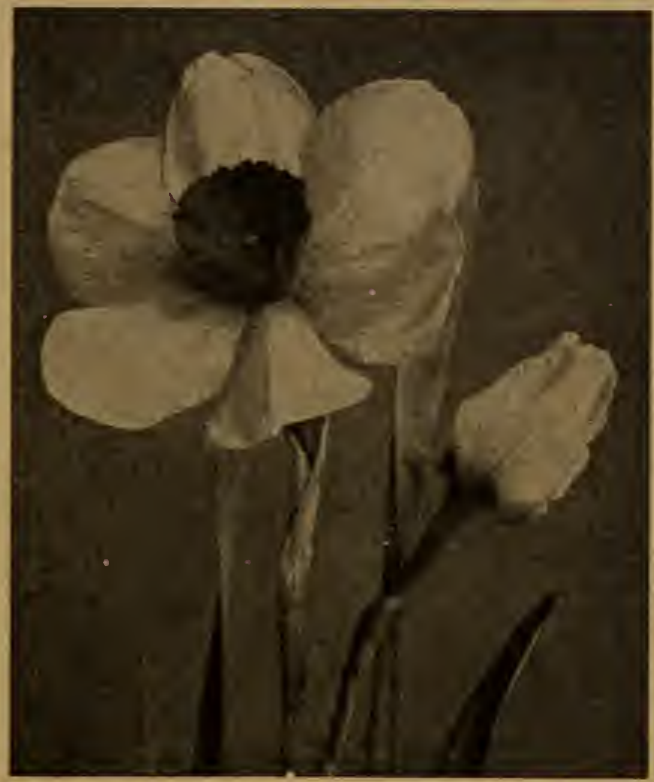

Incomparabilis, Will Scarlett. The contrast between perianth and cup is always well defined

\section{Incomparabilis, Will}

Scarlett. Extremely large cup of fiery orange-red, an unusual color in the Trumpet Narcissi. 40 cts. each, $\$ 4$ per doz.

Leedsii, Duchess of Westminster. Pure white perianth; canary-yellow cup, tinged with orange on the edges. \$I.25 per doz.

Leedsii, Evangeline. Pure white perianth; soft lemon cup. 20 cts. each, \$1.75 per doz.

Leedsii, Fairy Queen. Pure white perianth; creamy white cup. \$1.50 per doz., \$7.50 per Ioo.

Leedsii, Mrs. Langtry. Pure white perianth, with primrose cup. Free flowering; used extensively for mass planting. $65 \mathrm{cts}$. per doz., $\$ 4$ per 1oo, \$36 per I,000.

Leedsii, M. Magdeline de Graaff. Long white périanth; orange-rose cup. Free-flowering, often bearing two blooms to a stem. Desirable for mass planting. 65 cts. per doz., $\$ 4$ per Ioo, $\$ 36$ per I,000.

Leedsii, Queen of England. Pure white perianth; pale yellow cup. Good for massing. 65 cts. per doz., \$4 per Ioo, $\$ 36$ per I,000.

Leedsii, White Lady. Elegantly formed flower, with white perianth and canary-yellow cup. \$1.50 per doz., \$9 per 100. 


\section{POET'S NARCISSI}

Poeticus. The familiar "Poet's Narcissus," with pure white perianth and orange cup. One of the best for the border or for naturalizing, but not suitable for forcing. 60 cts. per doz., $\$ 4$ per I00, $\$ 35$ per I,000.

Poeticus, Horace. One of the latest introductions in this class; extralarge and unusually handsome flowers. Snow-white perianth with bloodscarlet cup. $30 \mathrm{cts}$. each, $\$ 3$ per doz.

Poeticus ornatus. Blooms earlier than the others, and can be used for forcing. Perianth is pure white, cup rich yellow with scarlet margin. Extra-size, double-nose bulbs, 65 cts. per doz., $\$ 4$ per r $00, \$ 35$ per I,000.

\section{DOUBLE NARCISSI}

Alba-plena odorata. Pure white; for outdoor planting only. $6_{5} \mathrm{cts}$.

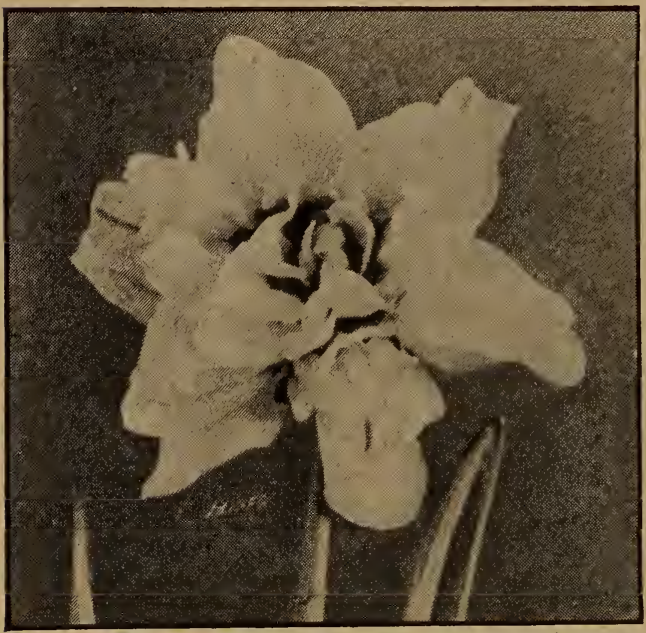

Orange Phœnix is a desirable variety for forcing per doz., $\$ 4$ per Ioo, $\$ 36$ per I,000.

Orange Phœnix. Excellent for forcing. Flowers large, full double, white with reddish orange center. 90 cts. per doz., $\$ 6.50$ per Ioo.

Sulphur Phœnix. Silvery white, with sulphuryellow center. These two varieties make a charming combination when grown in masses. 90 cts. per doz., \$6.50 per 100.

Von Sion. Flowers extra large, pure golden yellow. The most popular double variety for forcing. Extra - selected mother bulbs, \$I.50 per doz., $\$ 9$ per 100.

\section{JONQUILS}

These are the old-fashioned familiar garden flowers. They are very fragrant, of medium size, and pure yellow in color. Flowers grow in clusters and as a group will increase in size and value each year.

Campernelle odorus plenus (Queen Anne). Much larger than the common Jonquils. Color rich yellow. 6o cts. per doz., \$3.50 per ioo.

Campernelle rugulosus. Handsome flowers, with broad, clear yellow imbricated cup. 50 cts. per doz., $\$ 3.50$ per 100, $\$ 32$ per I,000.

Single Jonquils. 50 cts. per doz., \$3 per I00, $\$ 28$ per I, 000 .

Double Jonquils. 50 cts. per doz., \$3.50 per I00, \$32 per I, 000.

Ten per cent discount will be given on Bulb orders received before |July 10 


\section{SPECIAL LIST OF HOLLAND BULBS, AUTUMN, 1920}

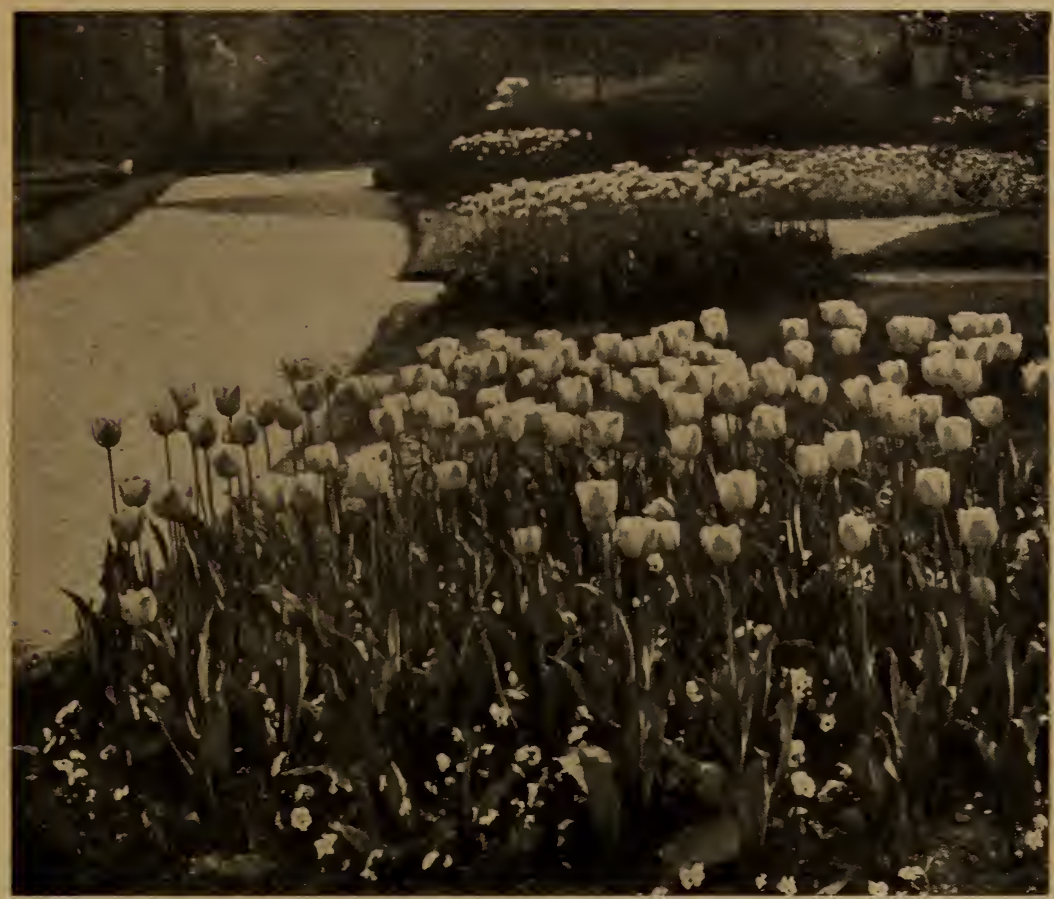

Darwin Tulips bloom later than the other classes. They are quite distinct in size and shape. See page 10

\section{TULIPS}

The great variety of dazzling colors, in every conceivable combination, makes the Tulip the most popular of the spring-flowering bulbs. By planting bulbs of the different classes, a display of bloom may be had for several weeks, beginning first with the early-flowering section and ending with the Darwins.

Tulips may be planted any time from the first of October until the ground freezes, and if the beds are later to be occupied by shallow-rooting plants, such as geraniums, coleus, etc., they may be allowed to remain a second year without lifting, merely by removing the tops as soon as they turn yellow.

If necessary, the bulbs may be carefully lifted as soon as they have ceased blooming and hilled-in in an out-of-the-way place until they have completed their growth, when they may be stored in a cool, dry place until fall. Planted in the hardy border and among shrubbery, they may be allowed to remain year after year undisturbed; but they will gradually deteriorate and will, in a few years, have to be replaced. 


\section{SINGLE EARLY TULIPS}

All the varieties in this list may be used with equal success for bedding or for forcing.

Not less than 6 bulbs of a variety sold.

Not less than 50 bulbs of any variety at the 100 rate, nor less than 500 bulbs of any one variety at the 1,000 rate.

To obtain the dozen rate your order must be for six bulbs or more of one variety. Less than six bulbs will be charged at the single rate.

Artus. A bright scarlet variety, which is extra fine for bedding or for forcing. 60 cts. per doz., \$4 per I 00, \$35 per I,000

Belle Alliance. One of the finest deep scarlet, single, early Tulips. 65 cts. per doz., $\$ 4.50$ per 100, $\$ 40$ per i, ooo.

Chrysolora. A large and extra fine pure golden yellow Tulip; desirable for bedding with red and white sorts. 65 cts. per doz., $\$ 4.50$ per Ioo, $\$ 40$ per I, 000

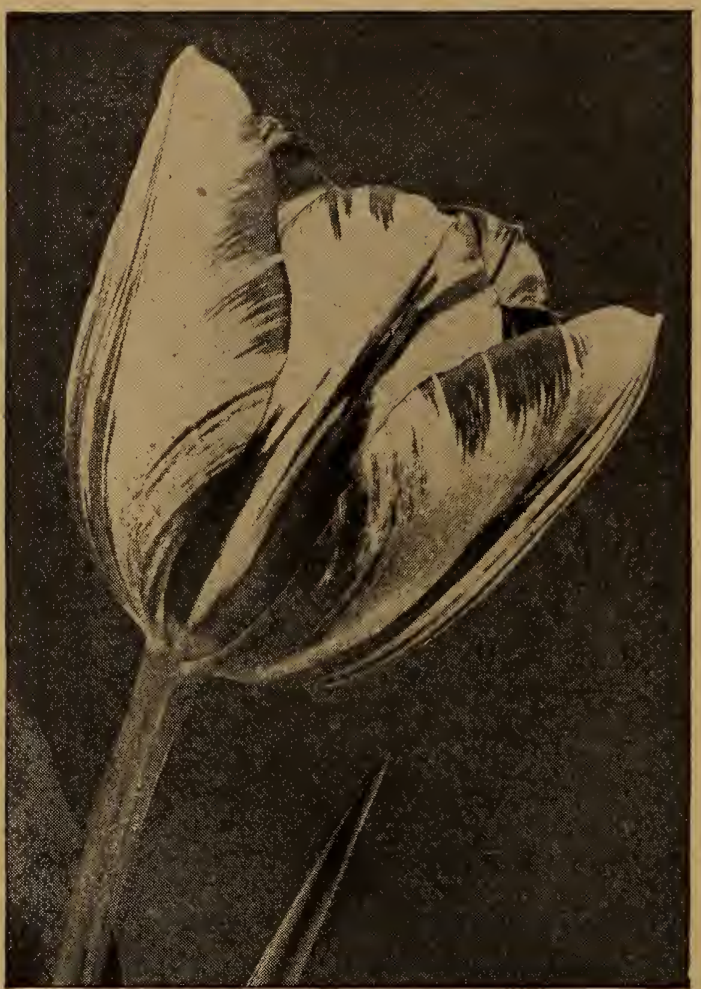

A typical specimen bloom of one of my Single Early Tulips

Cottage Maid. Soft pink, suffused with white. 65 cts. per doz., $\$ 4.50$ per 100, $\$ 40$ per I, 000 .

Duchesse de Parma. Orange-red. $65 \mathrm{c}$. per doz., \$4.50 per 100, $\$ 40$ per I,000.

Eleanora. A medium-sized purple-violet flower with white edge. 65 cts. per doz., $\$ 4.50$ per $100, \$ 40$ per I, 000.

Joost Van Vondel, Red. Deep red, feathered white. $6_{5}$ cts. per doz., \$4.50 per I00, $\$ 40$ per I,000.

Keizerkroon. One of the best Tulips for bedding. Flowers large, brilliant red, bordered with deep golden yellow. 60 cts. per doz., $\$ 4$ per 100, \$37.50 per I, ooo.

Lady Boreel (Joost Van Vondel, White). A recent introduction. Pure white; large and extra fine. 70 cts. per doz., \$5 per 100 , $\$ 45$ per I,000. 


\section{SINGLE EARLY TULIPS, continued}

La Reine. White, suffused with rosy blush. About I inches in height. 65 cts. per doz., \$4.50 per 100, \$40 per 1,000.

Pink Beauty. Rosy pink, slightly shaded white; unsurpassed in beauty and size. 95 cts. per doz., \$6.50 per 100, \$57.75 per 1,000.

Pottebakker. A popular variety for bedding. Flowers are rich scarlet with a yellow center. Height 13 inches. 65 cts. per doz., $\$ 4.50$ per 100 , $\$ 40$ per I,000.

Pottebakker, White. Cup-shaped, pure white flowers; blooms quite early. 85 cts. per doz., \$6 per I00, \$50 per I,000.

President Lincoln (Queen of Violets). Flowers large, deep crimsonpurple. Desirable for bedding and forcing. $65 \mathrm{cts}$. per doz., $\$ 4.50$ per 100 , \$40 per I,000.

Prince of Austria. Orange-red, and one of the best Tulips in color; very fragrant. 70 cts. per doz., $\$ 5$ per I00, $\$ 45$ per $1,000$.

Proserpine. A rich carmine-rose, with tinges of purple. Blooms are very large and come quite early. \$1.25 per doz., \$10 per I00, \$80 per I,000.

Rose Gris-de-Lin. A beautiful and useful variety. White shaded with delicate pink. 60 cts. per doz., $\$ 4$ per $100, \$ 37.50$ per 1,000 .

Standard Gold. Red, striped golden yellow. 70 cts. per doz., \$j per 100.

Standard Silver. White, distinctly marked and streaked with scarlet. 60 cts. per doz., \$4 per 100, \$37.50 per 1,000.

Thomas Moore. Bright orange, shaded with scarlet. Splendid for bedding. 60 cts. per doz., $\$ 4$ per 100, \$37.50 per 1,000.

White Hawk. One of the best white varieties; petals slightly fluted. 85 cts. per doz., $\$ 6$ per 100 , $\$ 50$ per I,000.

Wouverman. Dark violet. 60 cts. per doz., \$4 per Ioo, $\$ 36$ per I,000.

Yellow Prince. Golden yellow; the best of the low-growing yellow Tulips; sweet-scented. 60 cts. per doz., $\$ 4$ per 100, $\$ 37.50$ per I, 000 .

\section{SINGLE EARLY TULIPS IN SUPERFINE MIXTURE}

A choice collection made up from the best named Tulips. The bulbs will bloom at about the same time, and the flower-stems are about the same length-important points when selecting bedding varieties. The mixture is superior in every way. 50 cts. per doz., \$3.75 per Ioo, $\$ 35$ per 1,000 .

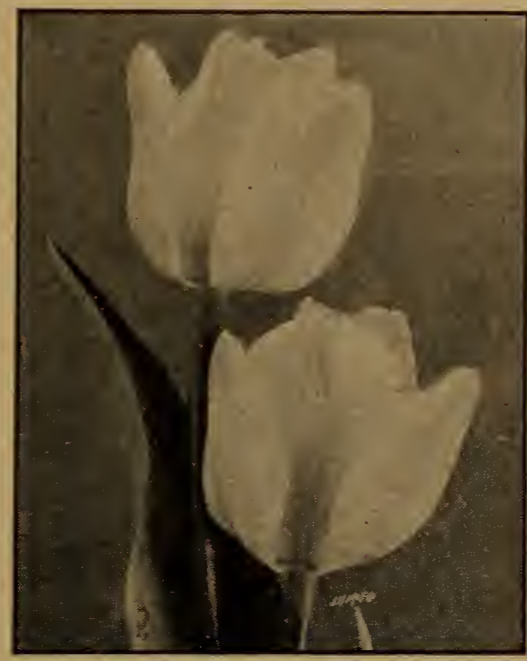

Chrysolora is one of the most popular yellow Tulips for bedding 


\section{DOUBLE EARLY TULIPS}

With few exceptions the Double Tulips should be used for bedding only, as they do not force so well as the single varieties. While the Double Tulips may not be quite so effective as the single sorts, the flowers are more durable, and, as they bloom later, they prolong the flowering period.

Usually it is advisable to use only one variety of Double Tulips in a bed, rather than to combine them as with the Single Tulips. Beds of different varieties can usually be arranged within a few feet of each other, thus permitting the characteristics of each variety to stand out distinctly, and also to give the effect of one large bed of double flowers.

Not less than 6 bulbs of a variety sold.

Not less than 50 bulbs of any variety sold at the 100 rate, nor less than 500 bulbs of one variety at the 1,000 rate.

To obtain the dozen rate your order must be for six bulbs or more of one variety. Less than six bulbs will be charged at the single rate.

Alba maxima. Flower-stems of medium length, surmounted by pure white blooms. 75 cts. per doz., $\$ 5$ per I $00, \$ 40$ per I, 000.

Couronne d'Or (Crown of Gold). A magnificent golden yellow flower, slightly shaded with orange; of great beauty and size, and one of the best for forcing. \$1 per doz., \$7 per I oo, \$60 per I, 000.

Couronne des Roses. Blooms are unusually large and of a deep, rich, rose-color. \$I per doz., \$7 per I00, \$60 per I,000.

El Toreador. Orange-scarlet, with edges of the petals margined with yellow. \$I.50 per doz., \$10 per Ioo.

Imperator rubrorum. A brilliantly glowing scarlet; good forcer. \$I per

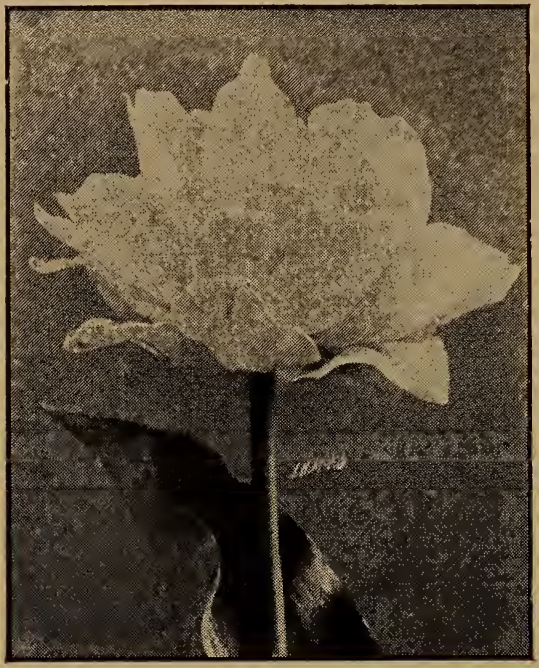

La Candeur is a white double Tulip extensively used for borders and beds doz., \$7 per Ioo, \$60 per i, 000.

La Candeur. Clear white; fine for bedding in contrast with pink and red sorts. 75 cts. per doz., $\$ 5.50$ per I00, \$45 per I,000.

Le Matador. Scarlet, outside of petals tinged with purple. Good forcer and bedder. \$I per doz., $\$ 7$ per I 0o, \$60 per I, ooo.

Murillo. Light pink blooms on medium height stems. Popular for either house or garden. 75 cts. per doz., \$5.50 per 1 oo, \$45 per I, 000 .

Salvator Rosa. Large, dark pink-and-white blooms; stems from Io to 12 inches long. \$I per doz., $\$ 7$ per I 100 , \$60 per I,00o.

Tournesol. A very showy Tulip, growing about I I inches high; red bordered with yellow. \$I per doz., $\$ 7$ per I oo, \$60 per I, 000 .

Wilhelm 11I. Orange-scarlet. Dwarf, useful for front of taller sorts, or in beds. 75 cts. per doz., $\$ 5.50$ per I00, $\$ 4.5$ per I, 000. 


\section{COTTAGE TULIPS \\ Single or May-Flowering}

Caledonia. Bright orange-red, with dark stems; beautiful and effective. 75 cts. per doz., \$5 per roo, \$40 per I,000.

Elegans. Dark crimson, with elegantly reflexed petals. 75 cts. per doz., \$5 per I00, \$40 per I,000.

Ellen Willmott. The finest May-flowering Tulip. Large, soft creamy yellow blooms. 85 cts. per doz., \$5 per 100, \$45 per I,000.

Fairy Queen. Rosy heliotrope, with broad amberyellow margin. 75 cts. per doz., \$5 per Ioo, \$40 per I, 000 .

Gala Beauty. Large golden yellow fflowers, blotched and striped crimson; showy in beds or borders. 75 cts. per doz., $\$ 4.50$ per I00, \$40 per I,000.

Gesneriana lutea (Improved Bouton d'Or). Handsome yellow flowers on long stems. 75 cts. per doz., \$5 per Ioo, \$40 per I,000.

Gesneriana major (Spathulata). Crimson scarlet with blue-black center. The best of its class. 75 cts. per doz., \$5 per Ioo, $\$ 40$ per I, 000.

Glare of the Garden. Dazzling scarlet. $75 \mathrm{cts}$. per doz., \$5 per Ioo, $\$ 40$ per I, 000 .

Golden Crown. Recommended for naturalizing, as it increases rapidly. Golden

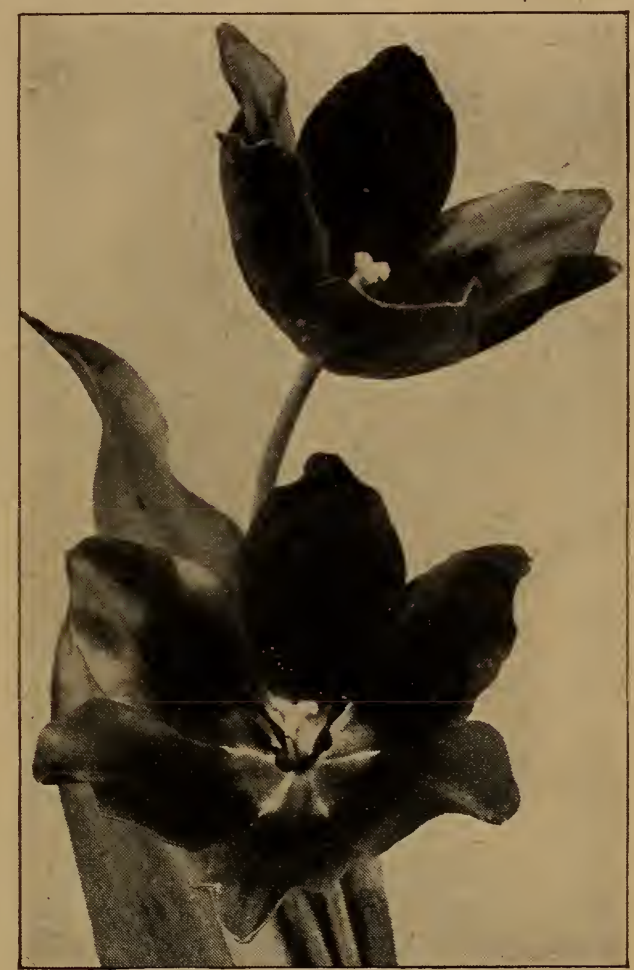

Gesneriana major has exceedingly vivid coloring yellow with red edges. 75 cts. per doz., $\$ 5$ per 100, $\$ 40$ per I,000.

Greigii. Orange-scarlet; spotted foliage. $\$ 2.25$ per doz., $\$$ I 4.50 per 100 .

Inglescombe Pink. Soft rose, flushed salmon. $75 \mathrm{c}$. per doz., \$5 per 100, $\$ 40$ per I,000.

Inglescombe Scarlet. Brilliant scarlet with black base; large flowers. 75 cts. per doz., \$5 per ioo, \$40 per I,00o.

Inglescombe Yellow (Yellow Darwin). Large globular flower. $75 \mathrm{cts}$. per doz., \$5 per I00, \$40 per I,000. 


\section{BERTRAND H. FARR-WYOMISSING NURSERIES CO.}

\section{COTTAGE TULIPS, continued}

Isabella (Shandon Bells). Carmine-rose, shaded white; desirable with some of the more striking colors. 75 cts. per doz., $\$ 5$ per I oo, $\$ 40$ per I, 000 .

John Ruskin. Bronzy rose, with sulphur-yellow edge, rosy lilac inside; very handsome. \$i per doz., \$7 per I00, \$60 per I,000.

La Candeur (Parisian White). White, changing to rose. $75 \mathrm{cts}$. per doz., $\$ 5$ per $100, \$ 40$ per 1,000 .

La Merveille. Salmon-rose, with yellow center; delicately scented, about 20 inches high. $75 \mathrm{cts}$. per doz., \$5 per Ioo, \$40 per I,000.

Moonlight. Lemon-, or canary-yellow; long oval-shaped flower. One of the handsomest Cottage Tulips. \$I per doz., \$7 per 10o, \$50 per I, 000 .

Oculus solis (Peacock Tulip). Crimson with black center. \$I per doz., $\$ 7$ per 100, $\$ 65$ per I,000.

Orange King. Deep orange, with delicate shadings of rose. $75 \mathrm{cts}$. per doz., \$5 per I0o, \$40 per I,000.

Picotee (Maiden's Blush). Pure white, margined rose; petals recurved. Useful for naturalizing. 75 cts. per doz., $\$ 5$ per Ioo, $\$ 40$ per I,000.

Scarlet Mammoth. Extra-large, dark crimson flowers. 75 cts. per doz., \$5 per I00, \$40 per I, 000.

The Fawn. Delicate pale rosy fawn, shading to blush-rose. An extrafine variety. $75 \mathrm{cts}$. per doz., \$5 per 100, \$40 per I,000.

Vitellina. Canary-yellow, turning to ivory-white. A large and exceedingly handsome variety. 75 cts. per doz., $\$ 5$ per $100, \$ 40$ per 1,000 .

\section{DARWIN TULIPS}

Darwin Tulips are highly recommended for massing in shrubbery and for providing contrasting colors in the spring garden. In form, the blooms are entirely distinct from all other classes of Tulips; they are unusually large and are borne on long stems. They may be forced if brought to the heat not earlier than January.

Not less than six bulbs of a variety sold. Not less than 50 bulbs of any sort at the 100 rate, nor less than 500 bulbs of any one variety at the 1,000 rate.

To obtain the dozen rate, you must order six bulbs or more of one variety; less than six bulbs will be charged at the single rate.

Anton Roozen. Rose-pink, tinged with apricot at base of the petals. \$I per doz., \$6.50 per I oo, \$60 per I,000.

Ariadne. Rich rosy crimson, shaded with scarlet. \$I per doz., \$6 per roo, \$54 per 1,000.

Baron de la Tonnaye. Bright rose, margined with blush. Extra-large flowers on long stems. \$1 per doz., \$6 per ioo, \$55 per I,000.

Clara Butt. Delicate salmon-pink. The best of its color. \$I per doz., $\$ 6$ per I00, $\$ 55$ per I,000.

Donders. Deep crimson, shading to white at the center. \$I per doz., $\$ 6$ per I00, \$50 per I,000.

Dream. Heliotrope, shaded violet. \$I per doz., \$6 per 100, \$55 per I, ooo.

Edmee. A splendid variety for late forcing; cherry-rose, edged with a lighter shade; large and beautiful. \$I per doz., \$6 per I0o, \$55 per I,000.

Europe. One of the newer introductions. Bright scarlet, shading to rose. \$I per doz., \$6.50 per 100, \$60 per I,000.

Faust. Dark violet-maroon. \$1.50 per doz., \$ I I per 100. 
DARWIN TULIPS, continued

Fra Angelico. Deep brownish black. \$i per doz., \$6 per I00, $\$ 50$ per I,000.

Gretchen. A delicate flesh-pink, cup-shaped flower. \$I per doz., \$6 per I00, \$50 per I,000.

Kate Greenaway. A late-flowering variety; white with tint of lilac-rose. Especially handsome. Si per doz., \$6 per I 00, \$50 per I,000.

La Tulipe Noire (The Black Tulip). Enormous flowers, nearly black. The most striking variety. \$1.25 per doz., \$8 per roo, \$65 per I, 000.

Laurentia. Fiery scarlet blooms which are unusually large and desirable for bedding purposes. Si per doz., \$6 per 100, \$50 per I,000.

Loveliness. Soft rosy carmine, making a beautiful contrast with darkercolored varieties. Si per doz., $\$ 6$ per $100, \$_{55}$ per $1,000$.

May Queen. Soft lilac-rose with white center. \$I per doz., \$5.50 per 100, \$5 per I,000.

Mme. Krelage. Bright lilac-rose with a lighter margin; extrafine. Si per doz., $\$ 6.50$ per 100, \$60 per 1,000 .

Mr. Farncombe Sanders. One of the best and showiest of the Darwins; blooms of immense size, brilliant scarlet in color. Si per doz., \$8 per Ioo, $\$ 65$ per I, 0oo.

Mrs. Cleveland. Delicate flesh - color, suffused with rose. $\$$ I per doz., \$6 per Ioo, \$jo per I,000.

Nauticas. Purplish rose, with dark violet center; desirable for garden or forcing. \$I per doz., \$6 per Ioo, $\$ 50$ per I, ooo.

Painted Lady. White, shaded with heliotrope; large and beautiful. \$r per doz., $\$ 6$ per Ioo, \$50 per I, 000 .

Philippe de Commines. One of the earliest Darwins for forcing; deep purple. \$1.25 per doz., \$8 per I0o, $\$ 65$ per I,000.

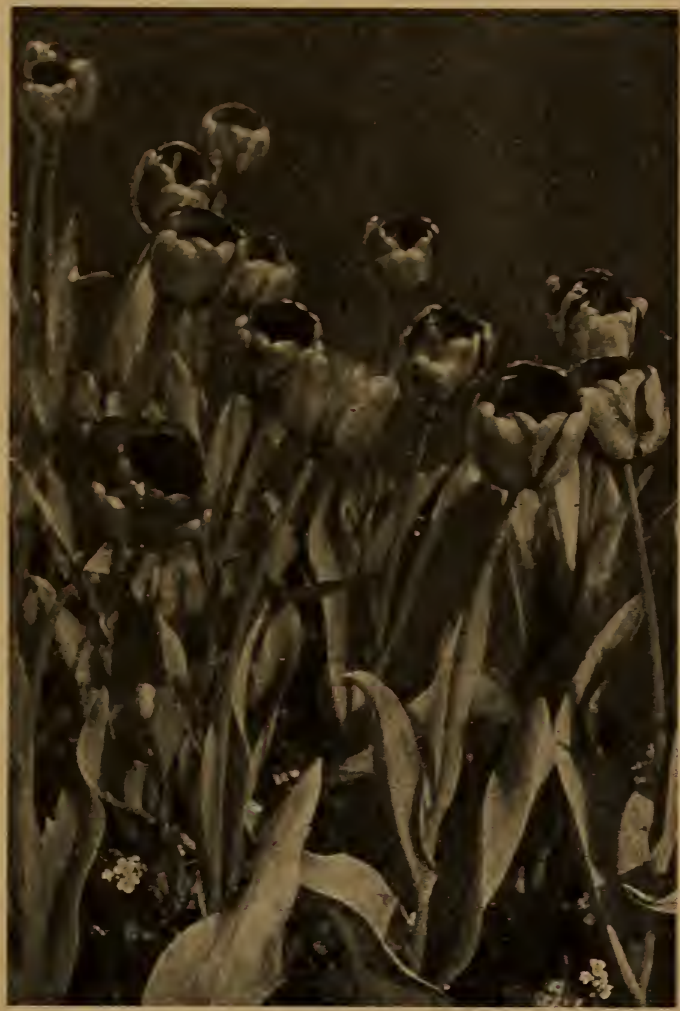

Mr. Farncombe Sanders is a rich scarlet with large blooms 


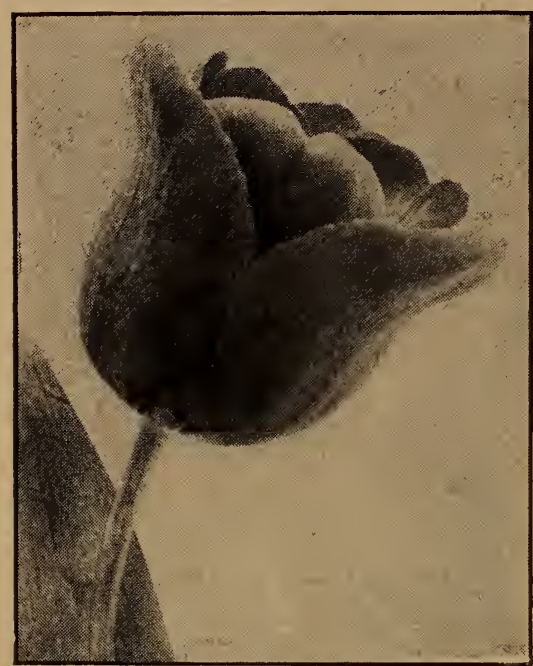

Zulu is startling when used in groups of twenty-five or more

DARWIN TULIPS, continued

Pride of Haarlem. Violet-rose, with a blue base. Blooms are extra Iarge. \$1 per doz., \$6 per I00, $\$ 55$ per I,000.

Psyche. Outside petals deep rose, inside shaded silvery rose, light blue base; cup-shaped blooms. \$I per doz., \$6.50 per I00, \$55 per I, 000.

Reverend Ewbank. Soft heliotrope or lavender-violet, darkened toward the base. \$I per doz., $\$ 6$ per 100, \$50 per I,000.

Suzon. Soft salmon-rose, shading to blush. Good Darwin Tulip for forcing. \$I per doz., \$6 per I oo, $\$ 50$ per I, 000 .

The Sultan. Velvety blackmaroon, with bluish base. \$I per doz., $\$ 6$ per $100, \$ 50$ per 1,000 .

Whistler. One of the new Darwins. Very attractive and one of the best. Maroon-crimson, base of the petals dark blue, with pure white lines. \$I per doz., \$6.50 per 100, \$55 per I,000.

White Queen (La Candeur). Rosy white, changing to pure white. \$I per doz., \$6 per Ioo, \$50 per I,000.

William Copland. Extra large and early; flowers light lilac, borne on long stems. \$I.25 per doz., \$8 per I00, \$70 per I,000.

William Pitt. Dark crimson, shading to purplish tint on outer petals. \$1.25 per doz., \$8 per I00, \$70 per I,000.

Zulu. Purplish black; a splendid large flower for forcing or for garden culture. $\$ 1.25$ per doz., $\$ 8$ per 100, $\$ 70$ per I,000.

Superfine Mixture of Darwin Tulips. $85 \mathrm{cts}$. per doz., $\$ 5.50$ per roo, \$50 per 1,000 .

\section{PARROT or DRAGON TULIPS}

This section of the Tulip family blooms in May. They take their name from the curiously curled and crested flowers which, in the bud state, are supposed to bear some resemblance to the head of a parrot. The colors and markings are very pronounced and distinct.

75 cts. per doz., $\$ 5$ per $100, \$ 45$ per 1,000

Amiral de Constantinople. Scarlet, with back markings.

Cramoisi Brillant. Crimson; very large flower.

Lutea major. Bright yellow, striped crimson and green.

Ten per cent discount will be given on Bulb orders received before July 10 


\section{SPECIAL LIST OF HOLLAND BULBS, AUTUMN, 1920}

\section{OLD DUTCH, or BREEDER TULIPS}

The Breeder Tulips are the unbroken forms of the old florists' Tulips. The blooms strongly resemble the Darwin Tulips, excepting that they have an entirely different range of color, comprising artistic tones of bronze, terra cotta, orange, and brown. Breeder Tulips are May-flowering, producing blooms of enormous size, and because they are vigorous growers are valuable for the garden. I have taken great pains to select only choicest varieties, and can heartily recommend these to anyone who wishes something especially fine.

Aspasia. Red, shaded with tones of salmon. \$I per doz., \$7 per roo, \$6o per I,000.

Cardinal Manning. Wine-red, flushed with rosy brown. \$i per doz., $\$ 7$ per 100, \$60 per I,000.

Clio (Bronze Queen). Soft buff, inside tinged with golden bronze. \$1.25 per doz., \$8 per I 00, \$75 per I,000.

Grand Maitre. Si per doz., \$7 per 100, \$60 per I,000.

Jaune d'CEuf (Sunrise). Ruddy apricot, edged with golden yellow. $\$$ I. 25 per doz., \$8 per I 00, \$65 per I,000.

Medea. Salmon-carmine, with heliotrope shading; an unusually large flower. $\$$ I.25 per doz., $\$ 8$ per I o0, $\$ 6$; per I,000.

Noire Veritable. Extremely dark purplish black. \$I.25 per doz., \$9 per 100, \$80 per I,000.

Prince of Orange (Orange Beauty). Orange-scarlet, shaded with light red. A large flower of unusual beauty. $\$ 1.25$ per doz., $\$ 8$ per I $00, \$ 6 ;$ per I, 000 . Queen Alexandra. Soft primrose, with black anthers. Si.25 per doz., $\$ 8$ per 100, \$6o per I, 000.

Yellow Perfection. Light bronze-yellow, edged with golden yellow: A Tulip of remarkable beanty. \$1.25 per doz., \$8 per 100, \$60 per I,000.

\section{CROCUSES}

When the spring sun begins to warm the ground, the little yellow Crocuses quickly respond to the bright rays. They are among the very earliest spring flowers, and are most effective when dotting the lawn without any fixed plan of arrangement. The bulbs can be strewn thickly over the surface and be set where they fall, merely lifting the sod with a knife or trowel, slipping the bulbs underneath, and pressing the sod back into place.

Mixed Crocuses. In separate colors, Blue, White, Striped, or AII Colors Mixed. 35 cts. per doz., \$2 per roo, \$1 5 per I,00o.

Named Crocuses. 60 cts. per doz., $\$ 3.50$ per 100, \$27 per 1,000. If wanted by mail, add ro cents per dozen extra.

Not less than six bulbs of any variety supplied

Albion. Dark violet, with stripes of light blue.

Baron von Brunow. Dark blue; velvety and beautiful.

King of the Whites. Snowy white; Iarge blooms.

Mammoth Yellow. Especially desirable for lawn planting.

Maximilian. Porcelain-blue; a new and Iarge variety.

Mont Blanc. White and one of the best of its class.

Sir Walter Scott. Large dark blue flowers, striped with white. 


\section{HYACINTHS}

For garden culture, the treatment is about the same as for Tulips, except

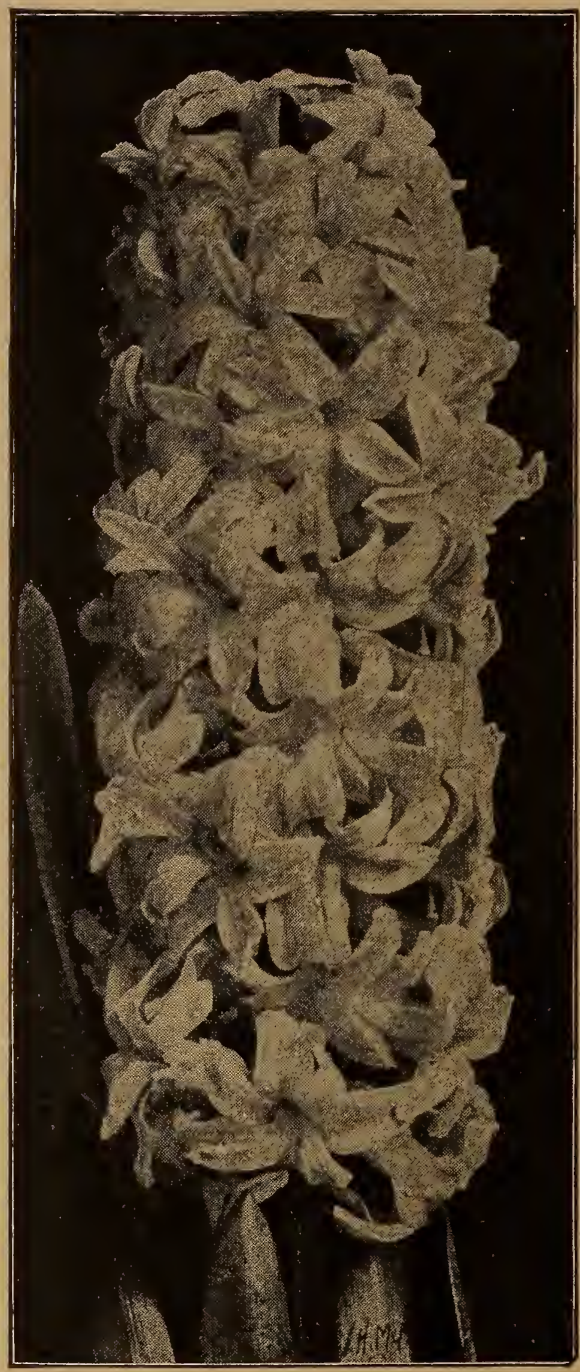

L'Innocence. One of the prettiest white Hyacinths; long, full truss that the bulbs should be set farther apart-say 6 to 10 inches.

For indoor culture the bulbs may be potted any time from September to December, using a light, rich soil containing plenty of well-rotted cow or sheep manure. Set the bulbs so that the tops are just above the surface.

The pots should then be placed outside, and covered with coal-ashes or some litter for a period of ten to twelve weeks, when the bulbs will be thoroughly rooted. Bring them in, a few at a time, for a succession of bloom as wanted. They should be brought into heat gradually; to place them at once in a room having a high temperature will cause them to flower prematurely.

If it is desired to grow them in glasses of water, the base of the bulb should barely touch the water. They should then be set in a cool, dark place until the glass is full of roots.

\section{FIRST-SIZE EXHIBITION}

Comparatively few bulbs of this quality come to this country-they are the very finest selections from the stock of several growers, are extra large and solid, and must not be confused with those often sold as "Exhibition Bulbs," which the Hollanders consider a second size. The bulbs here offered are used principally for forcing. I recommend them to all who wish the finest blooms. 


\section{SPECIAL LIST OF HOLLAND BULBS, AUTUMN, 1920}

\section{FIRST-SIZE EXHIBITION HYACINTHS, continued}

25 cts. each, $\$ 2.25$ per doz., $\$ 16$ per 100

\section{Single Red and Rose}

General de Wet. Extra-fine, soft pink, with large spike and bells. (Improvement on Baron Van ThuyII.)

Gertrude. Splendid, dark pink; large, compact spike.

Gigantea. Light pink; very compact spike.

La Victoire. Brilliant carmine-rose; extra fine. (Improvement on Amy.)

Moreno. Very heavy truss; bright rose; early.

Roi des Belges. Extra fine; dark red.

\section{Single Pure and Creamy White}

Albertine. Pure white; very early:

Grandeur a Merveille. Blush-white; large, handsome truss.

La Franchise. Creamy white.

La Grandesse. Splendid pure white; very large bells; perfect truss.

L'Innocence. Very fine; pure white.

\section{Single Light and Dark Blue}

Czar Peter. Light lavender-blue.

Enchantress. Delicate porcelain-blue; splendid truss.

Grand Maitre. Deep sky-blue; large, compact spike.

King of the Blues. Rich dark blue; splendid form; late.

Lord Derby. Bright porcelain-blue; large, compact spike.

Menelik. Glittering blue-black; truss and bells large; strong grower.

Queen of the Blues. Porcelain-blue; handsome spike.

Regulus. Bright blue; fine, large bells.

\section{Single Violet and Purple}

Lord Balfour. Violet; very early; enormous truss of fragrant bells.

Sir William Mansfield. Mauve; splendid truss; one of the best.

\section{Yellow Single Hyacinths}

King of the Yellows. Pure yellow; one of the best. May be grown indoors with the same success that attends its culture in the garden.

\section{Second-Size Single Hyacinths}

\section{0 cts. each, $\$ 1.75$ per doz., $\$ 12$ per 100 , $\$ 100$ per 1,000}

These bulbs are practically the same as those sold by most dealers as "First-Size." For bedding purposes they are extremely satisfactory and will produce large spikes of flowers, and I specially recommend these extraselect bulbs for outdoor use. I can supply the following varieties, and descriptions will be found in list of first-size bulbs.

Red and Rose. Gertrude, Gigantea, La Victoire, Moreno, Roi des Belges.

White and Creamy White. Albertine, Grandeur a Merveille, La Franchise, La Grandesse, L'Innocence.

Dark and Light Blue. Grand Maitre, King of the Blues, Lord Balfour, Queen of the Blues, Regulus. 


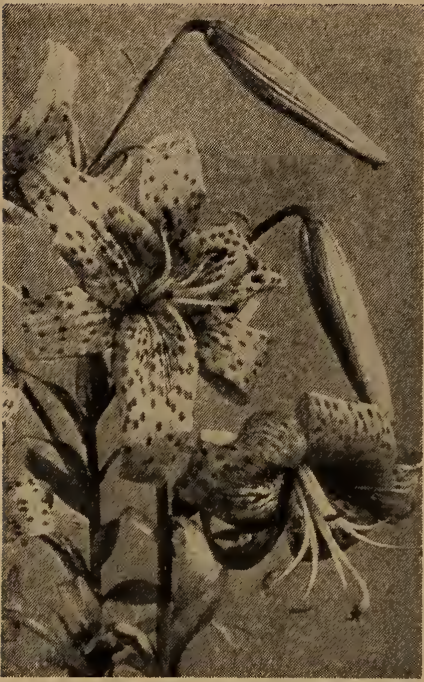

Lilium tigrinum

\section{HARDY LILIES}

With the exception of Lilium candidum, which seems to prefer an open position, most Lilies thrive best when planted in a semi-shaded situation, where the ground can be kept cool and moist by the protection of shrubs and a carpet of lawn grass. The bulbs should be planted from 6 to 8 inches deep, with a little sand or sphagnum moss under the base of each bulb.

To obtain the dozen rate on any bulbs your order must be for six or more of one variety. Less than six bulbs will be charged at the single rate.

Auratum (Gold-banded Lily). Very Iarge; white, spotted crimson, with a broad yellow band. 30 cts. each, \$3 per doz., $\$$ I 8 per IOO.

Brownii. Large trumpet, the inside pure white, the outside shaded chocolate-brown. \$I each, \$Io per doz.

Candidum (Madonna Lily). Pure white. Should be planted early for the best results. Extra-size bulbs, 30 cts. each, \$3 per doz., \$2 I per Ioo.

Excelsum (Testaceum). Nankeen-yellow, sometimes spotted with small, reddish dots. \$I each, \$1o per doz.

Hansonii (Yellow Martagon). Flowers bright orange, spotted with brownish purple. $50 \mathrm{cts}$. each, $\$ 5.25$ per doz.

Henryi (Yellow Speciosum). Dark reddish yellow, marked with brown spots. 75 cts. each, $\$ 8$ per doz.

Pardalinum. Similar to Superbum, but a brighter orange-scarlet. 30 cts. each, $\$ 3$ per doz., $\$ 20$ per 100.

Regale (Myriophyllum). New. White, shaded pink, with canaryyellow center. Hardy; desirable for forcing. \$1.25 each, \$1 2.50 per doz.

Speciosum album. White. 30 cts. each, $\$ 3$ per doz., \$18 per 100.

Speciosum Melpomene. White, heavily spotted and overlaid crimson. 30 cts. each, \$3 per doz., \$18 per Ioo.

Superbum (Turk's Cap). A native variety. Bright reddish orange, spotted yellow. 25 cts. each, \$2.50 per doz., \$I 5 per I 00.

Tigrinum splendens (Tiger Lily). Orange, spotted with black. 25 cts. each, \$2.50 per doz., \$I 5 per I oo.

Tigrinum splendens fl.-pl. Double-flowering variety of the Tiger Lily. 30 cts. each, \$3 per doz., \$1 8 per Ioo.

Umbellatum. Mixed, many shades of red and yellow. 25 cts. each, \$2.50 per doz., \$15 per Ioo.

Note.-European Lilies arrive about the middle of November. Japan Lilies, Auratum and Speciosum do not reach here until about the middle of December. We reserve the right to hold all orders for Japan Lilies for spring delivery in case they arrive too late for fall planting. 


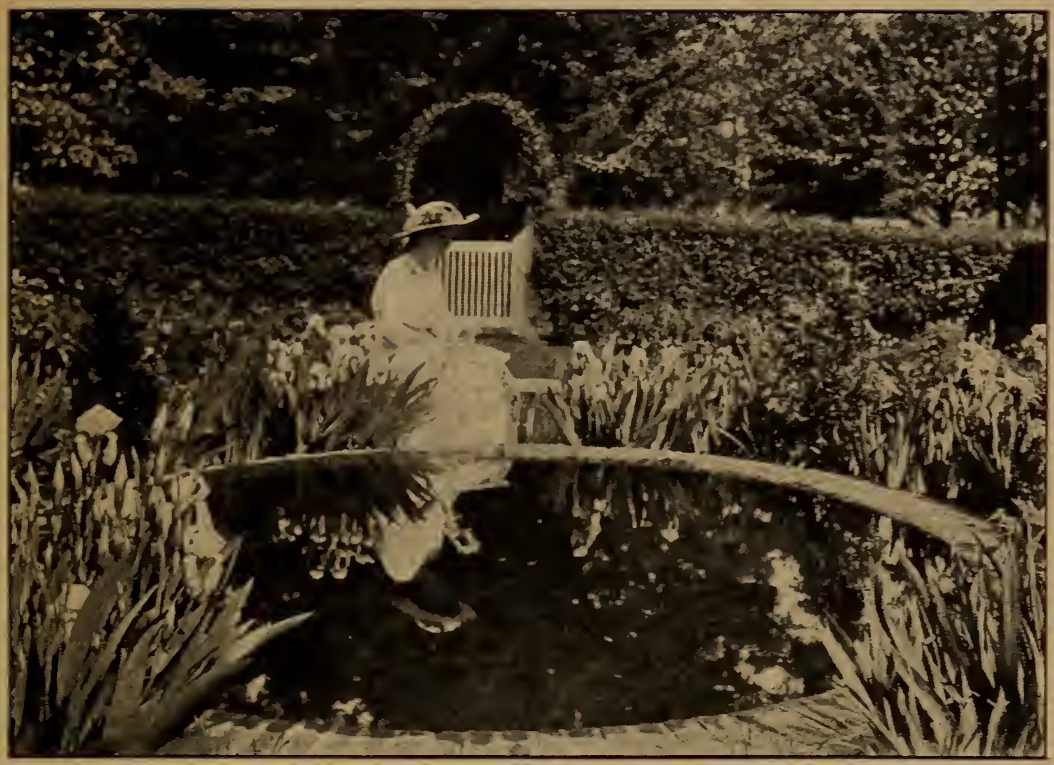

\section{Irises Usher in a Season of Glory in the Garden}

MORE THAN FOUR SCORE OF MY FAVORITES WHICH I COMMEND TO THE AMATEUR AND BEGINNER IN IRIS-GROWING

T $F$ you yield to the magic spell of the Iris, it will lead you across the border into a wonderland of delight, for an Iris-garden is a floral world in itself, so vast that to mention all the interesting forms would be impossible, as there are about one hundred and seventy distinct species, and varieties innumerable.

The passing of the Iris through the spring and summer months is like that of a grand procession, the first glimpses of which may be had when the dainty Alpines and Pumilas first appear in April, closely followed by the various dwarf forms in April and May, in ever-increasing boldness of form and color, till June ushers in the great Germanica family-the Bearded Irises with their broad masses of color. In quick succession come the tall Sibiricas and the still taller varieties of Aurea, Monnieri, and Gigantea, until, with a great burst of splendor, come the Japanese Irises, the crowning glory of all, with their great blooms a foot in diameter, rising on stately stems to a height of 5 feet, - the royal family, arrayed in richest blue and purple and gold, - and the pageant comes to an end.

In arranging the Iris-garden, much depends on the taste of the owner. Along walks and drives, the borders of the shrubbery, and near the waterside may be found ideal locations. The dwarf varieties make pretty edgings to Iarger beds, and are effective when planted in front of the taller kinds. 


\section{BERTRAND H. FARR-WYOMISSING NURSERIES CO.}

The chief aim of this booklet is, first, to assist the amateur gardener, whose efforts are limited only by the space at his command; and, second, to guide the beginner who as yet knows but little about these beautiful plants and who would be at a loss to select from the many hundreds of varieties noted in Farr's Hardy Plant Specialties, those varieties of Iris best suited to his purpose.

From my large collection I have selected a comprehensive list, which includes some of the most distinct varieties in each of the various classes, whose colors are truly magnificent, and whose blooming period covers the full season from the earliest to the latest.

The very dwarf April-flowering Irises must, of course, come first. These plants grow from 4 to 6 inches high, and prefer a dry, sunny situation. They are peculiarly suitable for edgings, for small groups in the rockery or perennial border, or for mass carpet-planting.

Possibly the very earliest is Pumila cærulea, which is a lovely pale azure-blue, and of unusually dwarf habit. Eburna is clear white, with shadings of cream; under favorable conditions it grows 12 to I 5 inches high. Among the deep blue Irises of this class Cyanea holds a high place.

Of the yellow varieties of April-flowering Irises, I would certainly select Florida, citron-yellow, shaded with deeper yellow, and Excelsa, whose clear yellow standard and falls are marked with a distinct orange beard.

Intermediate Irises, or medium dwarf varieties, are from 10 to 15 inches in height. They come into bloom immediately after the very dwarf sorts, usually in late April or early May. Ingeborg is a medium dwarf member of the family, with large flowers, almost snowy white in their purity.

Wallhalla, a rich combination of lavender standard and wine-red falls, makes a marked contrast with the large milky white blooms of Dorothea, which are usually slightly tinged with lilac. Helge, another good variety, is marked by pearl shadings on a ground of yellow.

In May the Irises begin to show their coming glories. Most of the varieties which bloom in this month throw out flower-stems from 20 to 24 inches in height; the blooms are larger than those of the earlier varieties, and are marked with a distinct beard. Your collection should by all means include Florentina, whose creamy white, fragrant blooms are splendid for cutting; Major, an immense flower with purple-blue standard and dark purple falls; Kochii, a rich and handsome claret-purple, and Flavescens, which is esteemed for its large, soft yellow, sweet-scented flowers.

Most of the bearded Irises begin their blooming season in June. Both the plants and flower-stems are of medium height, the latter rarely exceeding 24 inches. In the June-flowering varieties we seem to find a wider range of color, which varies from the deep rich crimson of Red Cloud (one of my own seedlings) to the pure white Mrs. H. Darwin, a beautiful and free-blooming sort.

Possibly the title of "finest pure yellow" would be awarded to Aurea, but the deep golden yellow blooms of Mrs. Neubronner certainly would create some doubt as to the justice of the award. Personal preference would again enter in when selecting a variety to represent the blues, for we have the pale blue Frederick compared with the deep blue of Atrocærulea, or the brilliant Blue Jay (another of my seedlings) contrasted with the pale 
lilac Mrs. Alan Gray. The nearest approach to a pink Iris is found in Rose Unique, whose bright violet-rose blooms come quite early.

Still other splendid varieties are included in the June-flowering Tall Bearded Irises, with flower-stems varying in height from 3 to $31 / 2$ feet, and crowned with magnificent large blooms. In this class Mme. Chereau is probably the best known because of the frilled white blooms, distinctly bordered with clear blue. If you are searching for an extra-large, clear, delicate Iavender Iris, you may safely conclude the search with Pallida dalmatica, which is generally conceded to be the finest of all.

Albert Victor ranks high among the light blues of this division, and is well supported by Othello, whose rich blue standard emphasizes the velvety purple of the falls. I cannot refrain from including one of my own seedlings here,-Juniata, the tallest of the bearded class, and whose clear blue, fragrant flowers are most lovely.

Jacquesiana, a rare variety, bears distinctly beautiful blooms; the falls are rich maroon, while the standard is bright coppery crimson. Plumeri is a free-blooming variety, combining coppery rose standard and velvety claret falls. Another beautiful variety is a lovely soft rose-pink, weII meriting the name of Queen of May.

Brilliant coloring is a distinguishing feature of all the tall bearded Juneflowering Irises, but some varieties seem to be more richly endowed than their fellows, and therefore need special mention. Among these Iris King is distinct because of the rich lemon-yellow standard and maroon falls which are bordered with yellow. Mithras raises a light yellow standard amid deep yellow falls that are bordered wine-red.

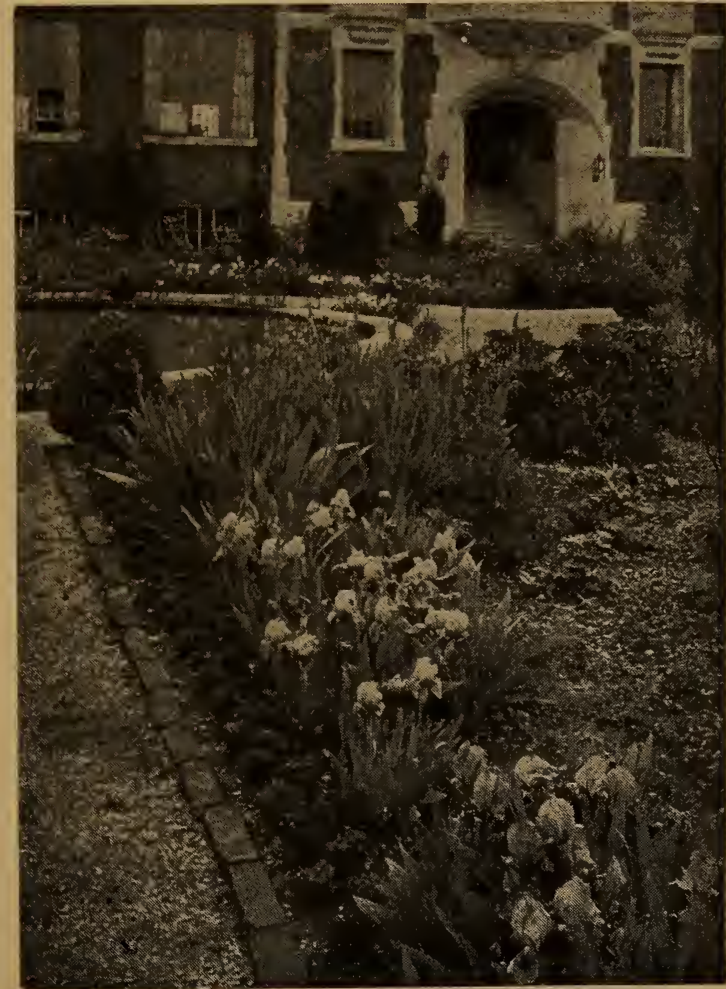

Farr's Irises at the home of "Country Life in America," Garden City, N. Y. 


\section{BERTRAND H. FARR-WYOMISSING NURSERIES CO.}

The light yellow standard and ultramarine-blue falls of Loreley seem to be made for a companion to Princess Victoria Louise, which carries a sulphur-yellow standard and plum-colored falls, the latter delicately bordered with cream. Darius attracts more than ordinary attention, for the standard is rich canary-yellow, supported by falls of lilac margined with white, and carrying a brilliant orange beard.

I should not be doing justice to myself, nor to my friends, if I did not mention some of the wonderful seedling Irises I have raised here at Wyomissing. All who have seen them have been unanimous in pronouncing them most beautiful. A collection of these seedling Irises was awarded a gold medal at the Panama-Pacific Exposition; all of them have been showered with words of praise when shown in non-competitive exhibitions. In ordinary cultivation the varieties average about 30 inches in height.

Chester Hunt carries a celestial blue standard, with falls of dark marine blue bordered with a paler shade, and stigmas of light blue. An immense light blue standard distinguishes James Boyd, while the broad falls are dark violet, tipped with lighter edge.

Long, drooping, creamy white falls, dotted and veined maroon, serve to introduce Mary Garden, though the pale yellow and lavender standard is quite pronounced in its beauty. I have never felt equal to writing an adequate description of Massasoit, for the peculiar shade of metallic Venetian blue is too elusive to be put on paper; it must be seen to be appreciated.

No Indian maiden could be more beautiful to her forest lover than is Minnehaha to the Iris lover; the dainty creamy white and yellow standard, the gracefully drooping falls of white and maroon, the clear yellow stigmas, and the fragrant odor, combine to make it one of the most desirable.

A bronzy yellow standard, with falls of deep maroon veined white and orange, and yellow stigmas, will fix Navajo securely in your memory. Both the standard and falls of Pauline are unusually large, rich pansy-violet in color, and possess a delicate fragrance. Powhatan carries a bishop-violet standard with deeper border, and falls of deep purple shaded crimson.

The lavender shadings on the standard of Quaker Lady, and the blue and gold of the falls make a combination at once quaint and pleasing. Wyomissing, another of my favorites, is formed of a creamy white standard suffused soft rose, and falls of deep rose shading to flesh at the border.

I feel so sure that the amateur and the beginner will desire these ten Wyomissing Seedling Irises that I am offering them in collection for $\$ 7$.

AII of the Irises mentioned in the foregoing pages belong to the Bearded class, or sun-lovers. They are entirely hardy, and quickly reach perfection in a warm, dry situation. In the following pages I shall include varieties belonging to the Beardless, or Apogon class; these thrive in moist situations, but can be grown successfully in any ordinary garden soil.

Siberian Irises have medium-sized flowers on long, slender stems. The flowers are produced freely, are of varying shades of blue with white markings, and extremely useful for cutting. George Wallace is an extra-fine variety, about 2 feet tall.

The Oriental Irises should be included here, and possibly I. sanguinea is the most conspicuous with brilliant blue flowers, the bud being inclosed 
in a crimson spathe. Snow Queen, a dainty ivory-white, and Blue King, a fine blue sort, were found in Japan by Mr. Peter Barr. Orientalis superba has unusually handsome foliage, of ten reaching the fuII length of the flower-stems which terminate in I a rg e violet-blue flowers.

Included with the beardless Irises are the Spuria and Gigantea species, which are tall growers, often reaching a height of from 4 to 5 feet. The flowers are beautiful in form, strongly resembling orchids or the giant-flowered Spanish Iris. The foliage is erect, sword-Iike, and highly ornamental. Both species delight in a rich, moist soil.

Spuria includes severaI varieties whose blooms range through pure white, porcelain - blue, to deep violet. Iris a u rea (species) comes from the

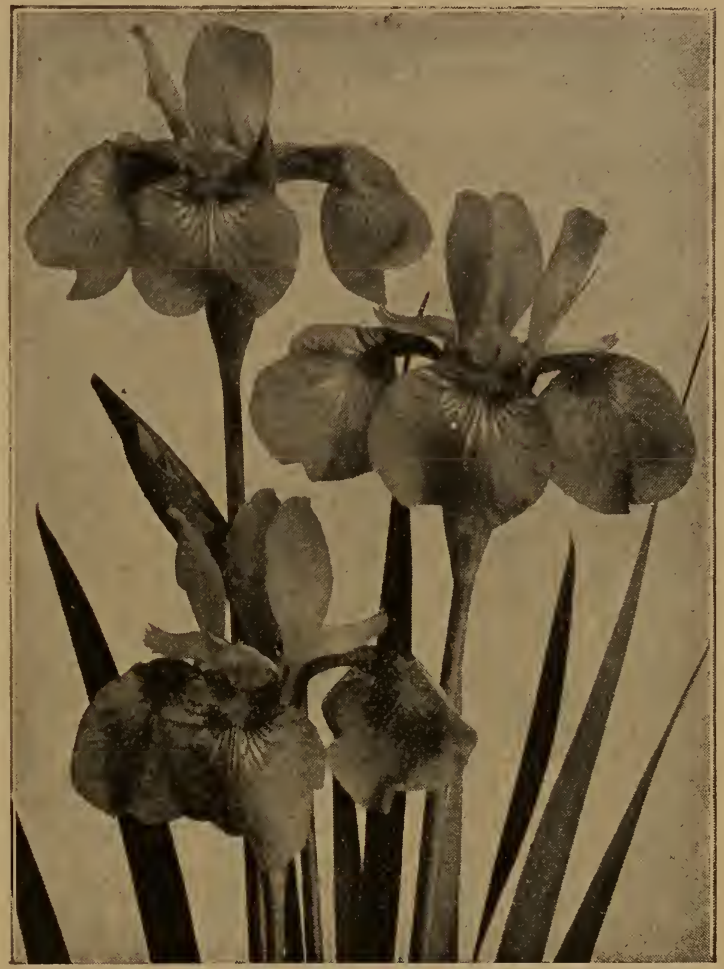

Iris sibirica

Himalaya Mountains; the deep golden yellow flowers are produced freely in June and early July. Ochroleuca, or Gold-Banded Iris, has Iarge white flowers with an orange-yellow blotch at base of the falls.

Among the Beardless Irises we find many that are interesting not only because of their habits and beauty of colors, but because of the quaint traditions that cluster around them. The variety I. tectorum, is commonly known as the "roof Iris" of Japan, where it is grown on the thatched roofs of the cottages. An ancient tradition says that once upon a time a woman went to a Shinto priest to inquire how she could give a blue tint to her hair. The priest told her to get the color of a flower which grew neither in heaven nor on earth. She tried the Iris flower from her cottage roof and attained the desired result. 


\section{BERTRAND H. FARR-WYOMISSING NURSERIES CO.}

\section{Prices of Irises Mentioned in the Preceding Pages}

\begin{tabular}{|c|c|c|c|}
\hline \multicolumn{2}{|c|}{ Each } & \multicolumn{2}{|l|}{ Each } \\
\hline mila cærulea ..........\$o & 25 & Juniata.... . & 50 \\
\hline urna............... & 20 & $\ldots \ldots \ldots \ldots$ & 50 \\
\hline 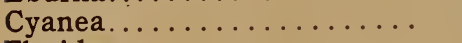 & 20 & eri.... & 20 \\
\hline$\ldots \ldots \ldots \ldots \ldots$ & 20 & Queen of May & 20 \\
\hline$\ldots \ldots \ldots \ldots \ldots$ & 20 & Iris King & 50 \\
\hline$\ldots \ldots \ldots \ldots \ldots$ & 20 & Mithras. & 35 \\
\hline$\ldots \ldots \ldots \ldots$ & so & Lor & 35 \\
\hline$\ldots \ldots \ldots \ldots$ & 3 & ss Victoria Louise. & 50 \\
\hline$\ldots \ldots \ldots \ldots$ & 3 & $\mathrm{Da}$ & 25 \\
\hline$\ldots \ldots \ldots \ldots$ & 3 & r Hunt & 75 \\
\hline$\ldots \ldots \ldots \ldots$ & 20 & Boyd & 50 \\
\hline$\ldots \ldots \ldots \ldots$ & 20 & rden. & 50 \\
\hline$\ldots \ldots \ldots$ & 35 & $\mathrm{Mr}$ & 50 \\
\hline$\ldots \ldots \ldots$ & 20 & haha. & 00 \\
\hline$\ldots \ldots \ldots$ & 75 & $\ldots \ldots \ldots \ldots$ & oo \\
\hline vin.......... & 20 & $\ldots \ldots \ldots$ & 50 \\
\hline$\ldots \ldots \ldots$ & 35 & $\ldots \ldots$ & 50 \\
\hline$r \ldots \ldots \ldots \ldots$ & 3 & $\ldots \ldots$ & 50 \\
\hline$\ldots \ldots \ldots$ & 2 & sing. & 75 \\
\hline$\ldots \ldots \ldots$ & 20 & Wallace....... & 35 \\
\hline$J$ & 75 & $\ldots \ldots \ldots$ & 20 \\
\hline A & 75 & Quee & 25 \\
\hline U & 75 & King & 25 \\
\hline . & 25 & lis superba. & 20 \\
\hline & 35 & lba. & 35 \\
\hline & 20 & Ha. & 35 \\
\hline & 25 & hroleuca........ & 35 \\
\hline
\end{tabular}

\section{JAPANESE IRIS (Iris Kaempferi)}

Much has been written of the wonderful Irises that exist in the mysterious gardens and temples of ancient Japan, so jealously guarded that they have never been permitted to reach the outside world.

Many years ago a collection of these Irises, said to be a duplicate of those in the garden of the Mikado, was brought to this country. At any rate it contained many beautiful varieties that have never been improved upon by later importations. It is to be regretted that some of the varieties in that collection have disappeared, and many of the remaining ones are to be found in limited numbers only here and there.

The Japanese Irises are the largest and showiest of all the Irises-seeing them for the first time one cannot withhold an exclamation of surprise, and having once seen can never forget their beauty. The flower-stems vary in height from 3 to 5 feet, and are crowned with gorgeous blooms showing a bewildering array of colors and combinations.

A well-enriched soil, with plenty of moisture during the growing and blooming season, meets all their needs. The soil should be kept loose around the plants, never permitting it to become baked or hard. Plants should be set the latter part of August or frrst of September-late planting 
had best be deferred until spring, unless the plants are well protected with a covering of straw, they will be thrown out by frost and lost.

Varieties not otherwise priced, $30 \mathrm{cts}$. each, $\$ 3$ per doz.

SPECIAL OFFER. Twelve in 12 choice named varieties, my selection, $\$ 2$. For mass planting, 100 in 10 choice named varieties, my selection, $\$ 15$.

Mixed varieties, unnamed, $\$ 12$ per $100, \$ 95$ per $1,000.25$ at the 100 rate, 250 at the 1,000 rate.

6 Yezo-Nishiki. Deep purple-maroon; three petals; tall.

9 Oniga-Shima. Six large, deep blue petals, with a white halo radiating into white lines. Very handsome.

I 2 Koko-No-Iro. Six large, royal purple petals, with a yellow center, radiating into lines. A most brilliant Iris.

13 Shirataki (White WaterfalI). Very tall; six broad, fluted, silvery white petals, with a golden band in the center.

17 Yomo-No-Umi (Boundless Sea). Deep lavender-blue; blue halo surrounds the yellow blotches, radiating out into feathers; petaloid stigmas violet; six petals. $50 \mathrm{cts}$. each.

2 I Ho-o-Jo (Ho-o-Castle). Yellow blotch, surrounded by a dark blue halo, shading to rich velvety purple; six large petals.

22 Osho-Kun (syn., Blue Danube). Dark Tyrian blue, yellow blotches radiating into white; six very large petals. Unapproached by any other variety of its color. \$i each.

23 Schichiukwa. Ruby-crimson, with white halo, center petals white, tipped purple. $50 \mathrm{cts}$.

$26 \mathrm{Yos} \mathrm{h} \mathrm{i} \mathrm{mo.}$ Eight petals; pure white, veined pale blue, petaloids lavender.

$27 \mathrm{Shigo-N} \mathrm{o-}$ Uranami. TaII; dark blue, white halo raciating white lines; six petals.

29. $\mathrm{K}$ a g a r a b i . White, traced and marbled ultramarineblue, petaloids blue; six petals.

$30 \mathrm{~W}$ a s e-Banri. Three white petals, delicately veined blue, dark blue st andards, edged white.

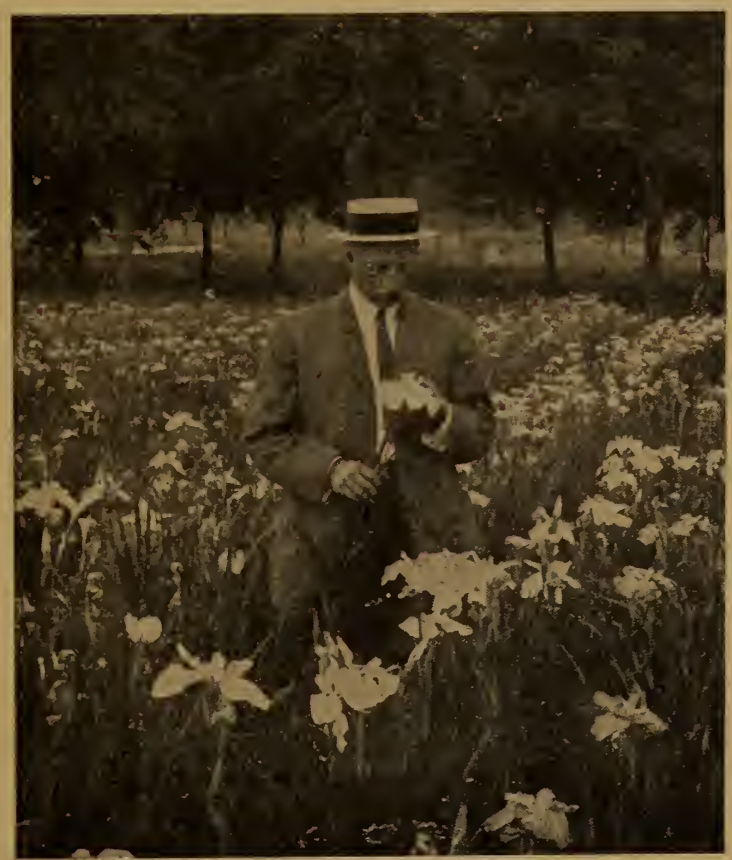

Iris Kaempferi, arrayed in richest blue and purple and gold 


\section{BERTRAND H. FARR-WYOMISSING NURSERIES CO.}

33 Hana-No-Nishiki. Royal purple, shaded crimson; tufted center; six petals.

34 Hana-Gesho. Tall; dark claret, overlaid blue; three large petals.

35 Tsuruki-No-Mai. Dark blue-purple, overlaid clear blue, bright yellow bar. 50 cts.

37 Choseiden. Silvery white, broad border of magenta-lilac; six petals.

38 Fuji-No-Mine. Gray-white, with a blue halo radiating dark blue lines, petaloids dark violet; six petals. $50 \mathrm{cts}$.

39 Tora-Odori (Dancing Tiger). Vinous purple, speckled and splashed gray; six petals.

4I Nishiki-Hitome. Three large petals; white, veined and overlaid rosy lavender, blue halo. 40 cts.

42 Uji-No-Hotaru. Dark violet-purple, shaded blue; six petals; Iate.

52 Shippo (Cloisonne). Tyrian-blue, suffused purple, feathered white; petaloid stigmas blue and white. $50 \mathrm{cts}$.

53 Zama-No-Mori. Falls white, with sky-blue zone in center; standards white, margined soft blue. 50 cts.

56 Sano-Watashi. Six white petals, with primrose blotches radiating into the white.

57 Bandai-No-Nami. Fine; Iarge; six petals; white, with fringed center.

70 Bluebeard. Six large petals; clear blue, with a white center.

75 Spotted Beauty. White, dotted rose-lilac; six petals. 40 cts. each.

76 T. S. Ware. Very double; dark garnet, veined white.

77 Mt. Fell. Six white petals, with deep blue lines; stigmas violet-blue, tipped white. $50 \mathrm{cts}$. each.

78 Perfection. Six broad, white petals with faint blue lines; petaloids and stigmas violet-blue, splashed white. $40 \mathrm{cts}$. each.

84 Nashiva. Blue, flaked and mottled white; six petals. $40 \mathrm{cts}$. each.

85 Tuyi. Tall; dark violet-blue, flaked white; three petals.

86 Robert Craig. Six large white petals, faintly veined maroon, base of petals maroon.

89 Kumo-No-Isho. Bright crimson-purple; Iarge flower; six petals.

9o Kuro-Kumo. Dark purple, overlaid with dark blue, yellow blotches; stigmas dark blue, bordered purple; six petals. $50 \mathrm{cts}$. each.

93 Otorige. Tall; purple; three petals.

96 Shimoyo-No-Tsuki. Three grayish white falls, faintly veined violet; three smaIl standards, violet, bordered and flaked white.

Ioo Kumo-No-Uye. Six large, frilled petaIs; deep indigo-blue, shaded purple.

I 27 Okubanri. Three petals; white, suffused blue, with a deep blue halo around the yellow center; small center petals plum; stigmas violetblue. 35 cts. each.

I 46 Idzumigawa. Gray ground, minutely veined maroon; six petals.

I 55 Helen Von Siebold. Three petals; white center, bordered violet-red.

I 56 Gekka-No-Nami. Six creamy white drooping petals.

I78 Hakubotan. Six Iarge petals; pure white.

I79 Hosokawa. Six petals; light violet-blue, veined white.

I 80 Kamato. Three petals; large, deep sky-blue flowers.

I8I Delice. Six light lavender petals, shaded lavender-pink, yellow blotches at base. 75 cts. each.

I 82 Lester Lovett. Six violet-blue petals, with white halo. $75 \mathrm{cts}$. each. 


\section{Farr's Hardy Plant Specialties}

(Seventh Edition)

TOR more than two seasons I have been making careful and accurate notes in the frelds, covering all the important points of the many perennials, shrubs, and evergreens growing in Wyomissing Nurseries.

This arduous labor was undertaken solely for the purpose of making the Seventh Edition of Farr's Hardy Plant Specialties of greater value to my friends and customers. It was my hope to issue the Seventh Edition in the fall of 1919, but the work was too great.

I am pleased to say, however, that the book is now in the hands of the printers and that we expect to have it ready for distribution before July 1. It will contain accurate descriptions of all the Irises which I myself have originated and collected; careful notes on upward of eight hundred varieties of Peonies which are growing in my garden and frelds. The book will also cover Hardy Chrysanthemums, Hardy Asters, Phloxes, Perennial Poppies, and a multitude of other perennials which should be in every American garden.

A copy of this new Seventh Edition will be sent to all of my regular customers just as soon as it is ready for mailing. If your name is not on my list, I will be pleased to send you a copy on request.

\section{BERTRAND H. FARR \\ Wyomissing Nurseries Co. Wyomissing, Penna.}




\section{Bertrand H.Farr-}

Wyomissing Nurseries Co. Wyomissing, Penna. 